Trivent Publishing

(C) The Authors, 2018

Available online at http:/ / trivent-publishing.eu/

TRIVENT

Series: Applied Ethics: From Bioethics to Environmental Ethics

\title{
The Moral Relationship of the Human and the Non-Human Animals in Light of Ethology
}

\author{
Alexander Krémer
}

University of Szeged, Hungary

\begin{abstract}
Animal suffering is an obvious consequence of different animal experiments and factory farming. Everybody can observe the terrible online data and images on this issue. From the birth of bioethics in the 1960s, it has become clear that animals should get more clear-cut defence than buman beings since they cannot protest and give informed consent. The Animal Rights Movement became stronger when Peter Singer published Animal Liberation in 1975. Tom Regan went further than Singer with his speciesism when he claimed that animals are "subject of a life" and they have moral rights. This chapter will show, in the light of modern ethology, that these views (Singer and Regan) cannot be founded philosophically, and that we should return to Immanuel Kant's standpoint. It is good enough to determine our moral relationship to animals, and above all, it is a provable standpoint.
\end{abstract}

Keywords: animal experiments; moral agents, human ethology; Vilmos Csányi; Immanuel Kant; Tom Regan; Peter Singer.

This is an Open Access article distributed in accordance with the Creative Commons Attribution Non Commercial (CC-BY-NC-ND 4.0) license, which permits others to copy or share the article, provided original work is properly cited and that this is not done for commercial purposes. Users may not remix, transform, or build upon the material and may not distribute the modified material (bttp:/ / creativecommons.org/licenses/by-nc/4.0/) 


\title{
The Moral Relationship of the Human and the Non-Human Animals in Light of Ethology
}

\author{
Alexander Krémer
}

\section{Introduction}

The relationship between animals and human beings is a complex problem. Especially if one perceives it within a historical perspective. This chapter will not undertake the monographic analysis of the problem, but will approach the theme through animal experiments. Besides animal farming (or factory farming), animal experiments show perhaps the most, what sort of pain humans can cause animals.

It is beyond question that millions of people purchase cosmetics, medicine, and household items day by day. It means that everybody uses products whose effects have previously been tested on animals. However, not only the significant cosmetic companies, chemical and pharmaceutic factories conduct so-called animal experiments, but also military laboratories (first of all those, where chemical weapons are created and tested), and the research institutes of the medical and veterinary universities. Whether it is called "animal testing" or "animal research," it refers to the experimentation carried out on animals. These are "animal experiments."

\section{The animal rights movement - Singer and Regan}

The animal rights movement (also known as the animal liberation movement, animal personhood, or animal advocacy movement), is a social movement which tries to end the rigid moral and legal distinction drawn between human and non-human animals. It also tries to end the status of animals as property and to end their use in research, food, clothing, and entertainment industries. It is one of the rare cases when a social movement was created which is, to a large extent, sustained academically by philosophers. The movement was allegedly founded in the UK in the early 1970 s by a group of post-graduate philosophy students, by the so-called "Oxford Group," but it 
was strengthened by Peter Singer (utilitarian liberationist) and Tom Regan (animal rights advocate).

Peter Albert David Singer is an Australian philosopher who taught applied ethics at different universities. He specialized in applied ethics and approaches ethical issues from a utilitarian perspective. Singer is best-known for his book Animal Liberation, regarded as the cornerstone of the animal liberation movement [1]. Not all members of the animal liberation movement share this view, and Singer himself has said the media overestimates his status. His views on animals and other issues in bioethics attracted him attention, as well as a degree of controversy.

Animal Liberation, published in 1975, has been cited as a significant influence on leaders of the modern animal liberation movement. The central argument of the book is an expansion of the utilitarian principle that "the greatest good for the greatest number" is the only measure of good or ethical behaviour. Singer argues that there is no reason not to apply this to other animals. He made the term "speciesism" popular, which was originally coined by Richard D. Ryder to describe the practice of privileging humans over other animals. In Animal Liberation, Singer argues against speciesism on the grounds that a being belongs to a certain species. He holds the interests of all beings capable of suffering to be worthy of equal consideration, and that giving lesser consideration to beings based on their species is no more justified than discrimination based on skin colour. He argues that animals should have rights based on their ability to feel pain more than their intelligence. He says, in particular, that while animals show lower intelligence than the average human, many severely intellectually challenged humans show equally diminished, if not lower, mental capacity. What is more, some animals have displayed signs of intelligence (for example, primates learning elements of American sign language and other symbolic languages) sometimes on par with that of human children, and therefore intelligence does not provide a basis for providing nonhuman animals any less consideration than mentally disabled humans.

Singer does not specifically contend that humans do not have to use animals for food insofar as they are raised and killed in a way that actively avoids the inflicting of unnecessary pain, but as such farms are uncommon, he concludes that the most practical solution is to adopt a vegetarian or vegan diet. Singer also condemns vivisection except where the benefit (regarding improved medical treatment and others) outweighs the harm done to the animals used.

Tom Regan is an American philosopher who was specialized in animal rights theory. He taught from 1967 until his retirement in 2001 at North Carolina State University. Regan is the author of numerous books on the philosophy of animal rights, including The Case for Animal Rights (1983), a book 
in a collection of studies which have significantly influenced the modern animal rights movement [2]. He argues in these studies that non-human animals are what he calls the "subjects-of-a-life," just as humans are. Furthermore, he argues that if we want to ascribe value to all human beings regardless of their ability to be rational agents, then we should be consistent and similarly ascribe it to non-humans. Regan argues in The Case for Animal Rights that non-human animals bear moral rights. His philosophy aligns broadly within the tradition of Immanuel Kant, though he rejects Kant's idea that respect is only due to rational beings. Regan points out that we routinely ascribe inherent value, and thus the right to be treated with respect, to humans who are not rational, including infants and the severely mentally impaired. The crucial attribute that all humans have in common, he says, is not rationality, but the fact that each of us has a life that matters to us; in other words, what happens to us matters to us, regardless of whether it matters to anyone else. In Regan's terminology, we each experience being the "subject-of-a-life." If this is the true basis for ascribing inherent value to individuals, he argues, in order to be consistent we must ascribe inherent value (hence, moral rights) to every subjects-of-a-life, whether human or non-human.

\section{The common precondition of Singer and Regan's theory}

Singer and Regan's argumentation has a common feature. They both refute rationality as the basis of morals and morality. They both believe that rationality is unacceptable as the basic criterion of becoming a moral agent. However, in my opinion, without rationality, we cannot speak about morals and morality. Rationality is a condition sine qua non, an indispensable condition of the moral phenomenon. It follows from this that animals cannot become moral agents!

Why can we state that animals cannot be moral agents? In order to answer this question, we first of all need argumentation not taken only from the history of philosophy, but from science as well. The philosophical argumentation in itself cannot satisfy our needs of verification because it can clarify mostly the standpoints within intellectual history, their relationships, and the contemporary scientific, theological and other views, which determined them. It is beyond question that the issue mentioned above needs a philosophical and ethical approach too. However, the exclusive exegesis of the earlier philosophical and ethical texts can mostly lead to obsolete results if we do not consider recent scientific recognitions. Thereby, I am arguing that not only an approach from the history of philosophy is needed, but also philosophical and ethical trains of thought, which are proved by recent results and argumentations of the positive sciences. 


\section{Alexander Krémer \\ The Moral Relationship of the Human and the Non-Human Animals... \\ Rationality as a necessary precondition of morals and morality - two arguments (choice and ethology)}

There are at least two clear arguments for my standpoint. The first one is a logical and experiential argument, and it goes mostly against Regan. The second one is a historical and ethological argument, and it goes mostly against Singer. According to the first argument, a moral agent must be rational since a moral agent has to know what is good and bad in a moral sense. Without this sort of knowledge, we cannot speak about a moral decision. The moral choice is always rational. Most people grow in a human community where some moral norms already exist, and the youngsters appropriate the basic moral norms and values together with their native tongue and community traditions.

According to my second argument, morals and morality are exclusively sociobistorical products. They were born in a particular phase of mankind's historical development when some sort of rationality had already existed. This "historical moment" is, of course, a rather long period of a historical transition, where moral norms were born from customs and taboos. Ethology comes here into picture because it is attached to my second argument.

Why can animals not become moral agents? As I have already mentioned, we first of all need scientific research and argumentation and not philosophical argumentation since the latter speaks only about the philosophers' standpoints of their times. What is more, an interdisciplinary research would be needed with the help of zoology, biology, sociology, sociobiology, neurology, evolutionary psychology, ethology, human-ethology, and so on.

Due to our limits, I mention here only ethology and human ethology. Ethology is a branch of knowledge dealing with animal behaviour and human character under natural conditions, considering their formation and evolution. Ethology is an evolutionary science, and its basic principle is that if we discover the evolutionary history of species, then we can also understand and explain the basic forms of their behaviour. This principle led to the creation of buman ethology (based on Charles Darwin's, Konrad Lorenz's and Niko Tinbergen's oeuvre), which science examines the biological basis of human behaviour, with particular attention to its evolutionary preconditions. From the three main trends of the human ethological research [a) human capabilities in primates; b) research on babies and toddlers; c) comparison of different human cultures], the most important for us is the first one: the comparison between humans and primates.

As professor Vilmos Csányi, a well-known Hungarian human ethologist says, "the buman being is only a primate from a biological point of view" [3]. Furthermore, Csányi also says that when comparing humans and animals it is forbidden to detach elements from the whole context of the evolutionary process. It is a buman behavioural complex, which has - according to Csányi three constitutive parts: 
1) new behavioural forms connected to the life of a group;

2) harmonization of the group activities;

3) actions and capabilities of construction. [3, p. 301]

The new behavioural forms are connected to the life of the group, and the most important evolutionary result is that a permanent and closed group structure was born. This evolutionary happening has several preconditions: settlement; decreased aggression in sharing food and sexuality; new forms of division of labour; mental representation of the group, and loyalty to the group. However, the most noteworthy fact is that these features cannot be found in primates.

The harmonization of the group activities mostly refers to the ability to organize a group and create new forms of synchronization. Its preconditions are empathy (synchronization of emotions), imitation (synchronization of behavioural patterns, which creates the possibility of teaching), disciplining, and the ability to follow rules. After a while, the synchronization of activities, emotions and behavioural patterns happens at the same time, not only through language but also through creating music, singing, dancing, rites, pictures, etc. These features cannot be found in primates.

The actions and capabilities of construction happened and developed in the following fields:

a) the usage of language (animal language is a closed system, but human language is an open system with almost infinite possibilities of creativity, which allows the mental representation of anything, conversation about anything, and abstract thinking)

b) we also discuss the construction regarding the usage and creation of tools (it promotes and strengthens a. and c.)

c) abstract thinking (the "creation" of time: past-present-future; the creation of ideal worlds, which allows the existence of mathematics, religion, arts, etc., and also morals).

It must be emphasized that the developments of these abilities of construction promote and strengthen each other! Furthermore, the group-structure, customs, taboos, technical and legal norms, etc. are also results of construction! It is beyond question that these capabilities of construction exist in animals only in proto-forms! [3, pp. 301-309].

Summarizing this ethological description, it should be highlighted that these remarks show only a small aspect of ethology and human ethology. However, it must be emphasized that these features of the human behavioural complex are intertwined and in mutual relationships. In Csányi's opinion, the most essential aspect of this is that the strong group-structure, the capacity of synchronization, and the activities of construction result, together, in a closed feedback loop. The reason for that is that the activities of construction are directed 
mostly at the group itself, and the synchronization activities strengthen its effects, and loyalty to the group makes it permanent. The most important consequences of these facts are that a) bumans are culture-creating beings, and b) bumans are determined by both biological and cultural evolution.

Returning to our question ("Why cannot animals become moral agents?"), the following five conclusions can be drawn:

- Morals and morality are not identical with their biological basis, as the roof and the walls are not identical with the foundation of the house.

- Morals and morality are exclusively socio-historical products. Neither moral norms, nor the concept of "moral good" existed in pre-historic times! It is provable that the Greeks were the first ones to discuss morals on the social level, and Aristotle wrote the first work dedicated to ethics, the Nichomachean Ethics.

- Human beings became moral agents through rationality, not through the ability to suffering. Furthermore, humans do not maintain the moral phenomenon through the ability to suffer, but through rationality.

- That is why Singer's idea of replacing rationality with ability to suffer cannot be a accepted

- Morals and morality are the results of human rationality, and are exclusively socio-historical products. Therefore Kant's idea is able to describe the relationship between humans and animals.

\section{Kant's moral theory on the relation between humans and animals}

Before summarizing Immanuel Kant's view on the relationship between humans and animals, let us show the main structure of his ethical system. The most important issue in Kant's ethics refers to what is missing, that is, God. I am persuaded that it is a secularized version of the Christian moral philosophy, and in Kant's case, morality is identical to rationality. According to traditional Christian ethics, every moral norm and principle is deducted from its ultimate basis, God. It is a deontological model of ethics since people believe that there is an Absolute, which is also the highest moral good -- thus, only this can lay the absolute foundation for morality. Although Kant says in the preface of the Critique of Pure Reason (2nd edition) that "Thus I had to deny knowledge in order to make room for faith," [4, p. 117], it only signifies the result of his method of criticism. In his ethics, God is replaced by Reason, and God functions as a mere postulate. The categorical imperative is namely a synthetic, a priori proposition since it is created exclusively by the pure reason for the practical reason: "Act only according to that maxim whereby you can, at the same time, will that it should become a universal law" [5, p. 71]. Furthermore, we can find the same importance of rationality in moral situations. What should we do to 
become moral in moral situations? We have to test our subjective, individual maxims (only this way, they can become absolute moral laws) on the categorical imperative, which does not contain any particular moral value. (The fourth formulation of the categorical imperative is an exception in some sense [5, p. 87]). The categorical imperative determines only a relation between our maxims and a universal moral law, and we have to understand this relationship and act for the sake of duty, which means the respect of the categorical imperative. If our action fulfils the categorical imperative only accidentally, then our action will be legal but not moral. It means that we have to act in an absolute rational way if we want to become moral persons. (From a moral point of view, we can find in Kant's system the subjective maxims, the objective and absolute moral laws, and the categorical imperative.) We may not forget, however, Kant's imperative, which states that we cannot consider any of our emotions, desires or inclinations in a moral decision ${ }^{1}[6]$.

Returning to our topic, it must be emphasized that Kant, following Aquinas, opposed the idea that humans have direct moral duties towards nonhumans. For Kant, cruelty to animals was wrong only because it was bad for humankind. In 1797, he argued that

violent and cruel treatment of animals is far more intimately opposed to man's duty to bimself, and he has a duty to refrain from this; for it dulls his shared feeling of their pain and so weakens and gradually uproots a natural predisposition that is very serviceable to morality in one's relations with other men $[7, \mathrm{p}$. 238].

Kant's philosophy is loaded with several self-contradictions, but it seems that he is correct in connection to our moral obligations towards animals. Namely, in his opinion, humans do not have direct moral obligations towards animals since animals are not rational beings. Such beings cannot exist as moral agents because they cannot make moral decisions, which are impossible without the knowledge of the moral good and bad, and the awareness of their difference. This does not mean that in Kant's opinion, one can commit anything towards animals, as he thought that we always have indirect moral obligations towards them.

1 This part of Kant's ethics is highly problematic, but I focus here only on one main issue: what is Kant's opinion about the moral relationship between the human and nonhuman animals, and why it is better, than Singer's and Regan's standpoint. The analysis of these other problems would need a separate article or monograph. However, I wrote more about this issue in my book: Krémer Sándor, Alapvetó etika (Szeged: JatePress, 2004). 
It means that contrary to most human beings, ${ }^{2}$ animals are not moral agents, but we, humans also have to be moral towards animals in order to maintain our human dignity. Every human being who is able to comply with this moral request, has already satisfied not only his or her duty to behave morally towards animals, but most importantly, the duty to maintain his or her human dignity.

\section{References}

[1] Regan, Tom, The Case for Animal Rights. University of California Press, 1983.

[2] Singer, Peter, Animal Liberation. New York: Harper Collins, 2002.

[3] Csányi, Vilmos. Az emberi természet biológiai gyökerei. Lecture at the Mindentudás University. Available online here:

http://web.t-

online.hu/csanyi14/Csanyi_Vilmos/Letöltés_files/mindentudas_egyeteme.pdf, 301. - CS-MIE (last time accessed: April 13, 2018).

[4] Kant, Immanuel, Critique of Pure Reason. (The Cambridge Edition of the Works of Immanuel Kant) Cambridge: Cambridge University Press, 1998.

[5] Kant, Immanuel, Groundwork of the Metaphysics of Morals. (A German-English Edition) Cambridge: Cambridge University Press, 2011.

[6] Krémer Sándor, Alapvetó etika. Szeged: JatePress, 2004.

[7] Kant, Immanuel, The Metaphysics of Morals. (Texts in German Philosophy) Cambridge: Cambridge University Press, 1991.

${ }^{2}$ For example, human babies are not moral agents since they are not rational enough or at all. Incompetency is a similar case, which shows that not only in the field of morals, but also in the criminal law, those human beings cannot be moral and legal agents, who are not rational enough, and I could enumerate other examples as well. 